\title{
Negative Regulation of Cell Differentiation
}

National Cancer Institute

\section{Source}

National Cancer Institute. Negative Regulation of Cell Differentiation. NCI Thesaurus.

Code C40740.

Cell Differentiation Inhibition involves interference or restraint of progressive and normally irreversible processes whereby restriction of the developmental potential of immature precursor cells results in increasing specialization of cell function and morphology. 